\title{
Isolated cleft lip
}

INSERM

\section{Source}

INSERM. (1999). Orphanet: an online rare disease and orphan drug data base. Isolated cleft lip. ORPHA:199302

Isolated cleft lip is a fissure type embryopathy extending from the upper lip to the nasal base. 